\title{
Implementasi Bioetika oleh Apoteker yang Bekerja pada Industri Farmasi
}

\author{
Gunawan Widjaja \\ Universitas Tarumanagara \\ Email korespondensi:widjaja_gunawan@yahoo.com
}

(Submit 15/03/2019, Revisi 05/09/2019, Diterima 20/122019)

\begin{abstract}
Abstrak
Bioetika selalu dikonotasikan dengan pelayanan kefarmasian, di mana apoteker berhubungan langsung dengan pasien. Dengan demikian timbul pertanyaan bagaimana dengan apoteker yang bekerja pada industri farmasi, yang tidak pernah berhubungan langsung dengan pasien. Apakah apoteker pada industri farmasi tetap wajib melaksanakan bioetika dalam pekerjaan kefarmasiannya. Penelitian ini dibuat dengan tujuan untuk menjawab dan menjelaskan bahwa apoteker yang bekerja pada bidang industri farmasi tetap wajib melaksanakan bioetika dalam pekerjaan kefarmasiannya tersebut. Penelitian ini adalah penelitian pendekatan kualitatif, yang bersifat deskriptif analitis. Data yang dicari dan dipergunakan adalah data sekunder yang merupakan merupakan kajian tentang konsep dan teori bioetika yang dihubungkan dengan pelaksanaan pekerjaan kefarmasian, khususnya dalam industri farmasi. Pada penelitian ini pembahasan tentang industri farmasi dibatasi hanya pada industri pembuatan obat jadi. Analisis dilakukan dengan melakukan kajian terhadap rangkaian pekerjaan kefarmasian dalam industri farmasi, khususnya dalam pembuatan obat jadi, yang wajib dilakukan oleh apoteker agar obat yang dihasilkan dapat memberikan hasil yang optimum bagi pasien. Hasil penelitian menunjukkan kegiatan produksi obat tidak lepas dari kewajiban apoteker untuk memastikan bahwa keempat pilar bioetika tetap dipenuhi. Mulai dari proses pengadaan bahan baku, pemilihan formulasi, proses pembuatan hingga pengemasan dan penyimpanan obat jadi, apoteker wajib mempertimbangkan bioetika dalam pelaksanaan pekerjaannya tersebut. Apoteker yang bekerja di sektor industri farmasi wajib melaksanakan empat pilar bioetika dalam proses produksi obat, meskipun dalam kegiatan produksi obat itu sendiri apoteker tidak berhubungan langsung dengan pasien.
\end{abstract}

Kata kunci: Bioetika, industri farmasi, apoteker, pekerjaan kefarmasian

\section{Outline}

- Pendahuluan

- Metode

- Hasil dan Pembahasan

- Kesimpulan

- Daftar Pustaka 


\section{Pendahuluan}

Bioetika adalah adalah suatu istilah yang pertama kali diperkenalkan pada tahun 1970 oleh Potter, seorang ilmuwan biologi. Dalam The Encyclopedia of Bioethics, bioetika diartikan sebagai studi tentang dimensi etika dari ilmu biologis dan ilmu pengobatan. Hingga pada tahun 1974 bioetika berkembang menjadi suatu disiplin ilmu sendiri'. Istilah tersebut dipakai untuk menggambarkan persoalan etika yang berhubungan dengan kehidupan. Masalah etika yang berkaitan dengan hidup dan kehidupan manusia sendiri sudah dapat ditemukan dalam Code of Hammurabi ${ }^{2}$. Istilah bioetik sendiri dalam beberapa kesempatan seringkali dipergunakan sebagai sinonim dari medical ethics (etika medis) yang dihubungkan dengan pengobatan umat manusia ${ }^{2}$.

Dalam konteks bioetika sebagai etika medis, bioetika selalu dikaitkan dengan pelayanan medis yang dilakukan oleh dokter terhadap pasiennya. Dalam melakukan pelayanan medis dokter selalu berhubungan langsung dengan pasiennya. Dalam berhubungan langsung dengan pasien itulah maka timbul masalah etika. Sumpah Hippocrates seringkali disebut dengan etika medis yang paling tua dan paling dikenal dalam dunia kesehatan ${ }^{3}$. Segala hal yang disebutkan dalam sumpah hipokrates tersebut merupakan hal yang berhubungan langsung dengan pelayanan medis dokter terhadap pasiennya.

Pelayanan medis oleh dokter tersebut juga dapat disamakan dengan kegiatan pelayanan kefarmasian yang diberikan oleh apoteker kepada pasiennya. Dalam pelayanan kefarmasian, baik pelayanan di rumah sakit, klinik, puskesmas maupun apotek, apoteker berhubungan langsung dengan pasien, dan memberikan semua pelayanan kefarmasian yang dapat diberikan olehnya. Dalam pekerjaan kefarmasian, apoteker tidak hanya melakukan pelayanan kefarmasian, melainkan juga melakukan berbagai kegiatan lain yang tidak secara langsung berhubungan dengan pasien yang memerlukan obat, seperti misalnya apoteker yang bekerja pada industri obat, yang memproduksi obat. Apakah apoteker-apoteker tersebut juga menerapkan bioetika dalam kegiatan produksi obat yang dilakukan oleh mereka?

Penelitian ini dibuat dengan tujuan untuk menunjukkan bahwa para apoteker yang bekerja pada industri, meskipun dalam pekerjaan kefarmasiannya tidak secara langsung berhubungan dengan pasien, bioetika tetap berlaku bagi mereka. Dalam hal ini penelitian dibatasi hanya pada pembuatan atau produksi obat jadi.

\section{Metode}

Penelitian ini menggunakan bahan berupa data sekunder, yaitu data yang sudah tersedia, khususnya merupakan data publik, yang memuat informasi yang berhubungan dengan kegiatan apoteker dalam industri farmasi.

Data penelitian diperoleh melalui studi literatur dengan menggunakan mesin pencari "google search" dengan kata kunci utama "bioetika" dalam bahasa Indonesia atau "bioethics" dalam bahasa Inggris, dengan kata kunci pembantu "peran", "industri farmasi" dalam bahasa Indonesia atau "role", "pharmaceutical industry" dalam bahasa 
Inggris. Data penelitian yang terkumpul kemudian disortir secara kualtitatif dengan mencari hubungan dan keterkaitannya dengan tujuan penelitian.

Penelitian ini adalah penelitian deskriptif analitis dengan pendekatan kualitatif. Dikatakan deskriptif karena penelitian ini menjelaskan dan menjabarkan terlebih dahulu bioetika, yang kemudian dianalisis dalam kaitannya dengan pelaksanaan pekerjaan kefarmasian oleh apoteker dalam industri farmasi, khususnya pada pembuatan atau produksi obat jadi. Pendekatan kualitatif dilakukan oleh karena penelitian ini tidak menggunakan statistik sebagai alat pengolahan data untuk menarik kesimpulan, melainkan dengan menggunakan pengetahuan penelitian untuk melakukan analisis secara mendalam terhadap objek penelitian untuk menarik kesimpulan.

\section{Hasil dan Pembahasan}

\section{A. Memaknai dan Memahami Bioetika}

Seperti telah disebutkan sebelumnya bahwa bioetika adalah suatu istilah yang menujuk pada etika yang berhubungan dengan kehidupan manusia. Yang dinamakan kehidupan manusia ini, dimulai sejak manusia berada dalam kandungan (the beginning of life) ${ }^{2}$ hingga pengakhiran kehidupan manusia (defining death) ${ }^{3}$. Sebagai etika yang berhubungan dengan kehidupan manusia, dikenal 4 pilar pokok dalam bioetika atau etika medis. Ke-4 pilar tersebut adalah otonomi, beneficence, non-maleficense dan justice $^{2,4-8}$. Pemahaman mengenai ke-4 pilar bioetika tersebut akan menjelaskan berbagai hal yang berhubungan dengan informed consent, end of life issues, abortion, euthanasia, kerahasiaan, akses ke pelayanan kesehatan ${ }^{5}$. Dalam sumber referensi yang disebutkan di atas ${ }^{4,6-8}$, praktik bioetika juga selalu dikaitkan dengan intervensi medis yang berhubungan dengan hidup dan kehidupan manusia. Dokter wajib memberikan informasi atas setiap intervensi medis yang akan dilakukan agar pasien dapat menentukan sikapnya untuk menyetujui atau tidak intervensi yang disarankan tersebut, dan bahwa setiap intervensi medis yang dilakukan harus memberikan manfaat dan tidak boleh menimbulkan kerugian bagi pasien. Pemberian intervensi tersebut tidak boleh pilih kasih dan wajib diberikan secara setara bagi semua pasien.

Apoteker yang bekerja dalam pelayanan kefarmasian, yang identik dengan kegiatan farmasi klinik $^{9,10}$ wajib untuk melaksanakan prinsip pemberian obat yang rasional, yang diantaranya memuat prinsip $4 \mathrm{~T}$ dan $1 \mathrm{~W}$ yang kemudian berkembang hingga menjadi prinsip $8 \mathrm{~T}$ dan $1 \mathrm{~W}^{11}$. Dalam dispensing dan pemberian obat berdasarkan pada resep dokter, maka apoteker wajib melakukan pengkajian terhadap resep dengan menanyakan, memperoleh dan memberikan informasi secara langsung tentang segala hal yang perlu diketahui dan/ atau disampaikan olehnya terkait dengan dispensing yang dilakukan. Hal yang sama juga berlaku untuk pelayanan obat-obat yang tidak memerlukan resep dari dokter. Dalam pelayanan ini, tugas dan peran apoteker dalam berkomunikasi untuk memperoleh dan memberikan informasi yang cukup tidaklah berbeda dengan peran dokter dalam pelayanan medis. Dalam semua komunikasi yang dilakukan dengan pasien tersebut, maka ke-4 pilar bioetika dapat dilaksanakan langsung oleh apoteker. Melalui komunikasi pasien dapat memutuskan untuk membeli dan selanjutnya mengkonsumsi obat tersebut dengan segala akibat dan efeknya. Komunikasi tersebut memungkinkan pemberian obat yang efektif karena dikonsumsi 
dengan memenuhi $8 \mathrm{~T}$ dan $1 \mathrm{~W}$, serta dapat mengurangi penderitaan pasien dan menghindari pasien dari penderitaan lebih lanjut atau bahkan penderitaan lain. Informasi yang disampaikan dan konseling yang diberikan harus diberikan sama kepada setiap pasien tanpa pembedaan.

\section{B. Peran Apoteker yang Bekerja pada Industri Farmasi}

Apoteker yang bekerja pada industri farmasi yang melaksanakan pekerjaan produksi obat di pabrik, apoteker berkewajiban untuk melaksanakan tugasnya sesuai dengan pedoman yang sudah ditetapkan secara baku dalam bentuk Good Manufacturing Practices (GMP). Semua kegiatan yang dilakukan dalam proses GMP tersebut adalah untuk memastikan mutu obat yang baik. Kegiatan GMP yang dimulai dari proses pengadaan bahan baku, pemilihan formulasi, proses pembuatan hingga pengemasan, pelabelan dan penyimpanan obat jadi adalah kegiatan yang dilaksanakan agar obat yang dibuat memberikan hasil yang diharapkan. Selanjutnya informasi yang ada pada label atau kemasan memungkinkan pasein untuk memperoleh pemahaman yang cukup dan relevan untuk memutuskan membeli dan mengkonsumsi obat tersebut. Selain itu pasien juga memperoleh informasi tentang manfaat dan kerugian dan risiko yang dapat terjadi apabila ia mengkonsumsi obat tersebut. Dengan demikian pada dasarnya kegiatan pemberian informasi obat dan konseling yang dilakukan secara lisan oleh apoteker yang memberikan pelayanan kefarmasian yang bekerja pada fasilitas kesehatan juga dilaksanakan oleh apoteker yang bekerja pada pabrik yang membuat obat dalam industri farmasi. Hanya saja pemberian informasinya diberikan secara tertulis.

\section{Kesimpulan}

Dalam kaitannya dengan kegiatan apoteker dalam proses produksi obat, meskipun apoteker tidak berhubungan langsung dengan pasien, namun kegiatan yang dilakukan oleh apoteker tersebut berhubungan langsung dengan hidup dan kehidupan manusia. Output berupa obat yang diproduksi memuat informasi yang secara langsung dipergunakan oleh orang-orang yang akan mengkonsumsi obat tersebut atas pilihan mereka, baik untuk obat non-preskripsi atau atas persetujuan mereka untuk obat yang dipreskripsikan. Dengan demikian berarti apoteker yang bekerja di sektor industri farmasi wajib melaksanakan empat pilar bioetika dalam proses produksi obat dalam bentuk pelaksanaan Good Manufacturing Practices.

\section{Daftar Pustaka}

1. Nancy S, Jecker, Albert R. Jonsen dan Robert A. Pearlman. Bioethics: An Introduction to the History, Methods, and Practice. Jones \& Baartlett: New Delhi. 2010; 3.

2. Carolyn Johnston dan Penelope Bradbury. 100 Cases Clinical Ethics and Law. CRC Press: London. 2016.

3. President's Commission for the Study of Ethical Problems in Medicine and Biomedical and Behavioral Research. Defining Death; Medical, Legal and Ethical Issues in the Determination of Death. US Govt. Printing Office: Washington. 1981.

4. Helga Kuhse dan Peter Singer ed. A Companion to Bioethics. $2^{\text {nd }}$ ed. WileyBlackwell: Singapore. 2015: 3-6, 15-23. 
5. Jane Runzheimer dan Linda Johnson Larsen. Medial Ethics for Dummies. Wiley Pub.: Indianapolis. 2011: 9-32.

6. Akira Akabayashi, Satoshi Kodama dan BT Slingsby. Biomedical Ethics in Asia: A Casebook for Multicultural Leaners. Mc Graw Hill: Singapore. 2010; 4.

7. Claudia Carr. Couse Notes Medical Law and Ethics. Routledge: London, 2013;99115.

8. Michael Wilcockson. Medical Ethics. Hodder Education: London. 2008, 1-16.

9. Charles D. Hepler. "Clinical Pharmacy, Pharmaceutical Care, and the Quality of Drug Therapy". Pharmacotherapy. 2004;24(1):1491-1498

10. Agata Gurzawska. Ethics Assessment in Different Field: Pharmaceutics. Satori: (n.p). 2015.

11. Rusli. Modul Bahan Ajar Cetak Farmasi: Farmasi Rumah Sakit dan Klinik. Kemenkes: Jakarta. 2016, 105-111. 